\title{
KEEFEKTIFAN MODEL PEMBELAJARAN MAKE A MATCH DAN CARD SORT BERBANTUAN PUZZLE DITINJAU DARI HASIL BELAJAR SISWA KELAS 4 SD
}

\author{
Tisia Selvy Fynata' ${ }^{1}$, Mawardi $^{2}$, Suhandi Astuti ${ }^{3}$ \\ ${ }^{1}$ Pendidikan Guru Sekolah Dasar, Universitas Kristen Satya Wacana, 292014507@student.uksw.edu \\ ${ }^{2}$ Pendidikan Guru Sekolah Dasar, Universitas Kristen Satya Wacana, mawardi@staff.uksw.edu \\ ${ }^{3}$ Pendidikan Guru Sekolah Dasar, Universitas Kristen Satya Wacana,suhandi.astuti70@gmail.com
}

\section{IINFO ARTIKEL}

Riwayat Artikel:

Diterima: 14-04-2018

Disetujui: 21-04-2018

\section{Kata Kunci:}

Make a Match

Card Sort

Puzzle

Hasil Belajar

\section{ABSTRAK}

\begin{abstract}
Abstrak: Tujuan penelitian ini untuk mengetahui keefektifan model pembelajaran Make a Match dan Card Sort berbantuan puzzle ditinjau dari hasil belajar siswa kelas 4 di SD Gugus Diponegoro. Penelitian ini menggunakan jenis kuasi eksperimen. Hasil nilai signifikansi diperoleh nilai sig. (2-tailed) 0,022 dan sign.(1-tailed) 0,0105 dengan thitung 2,328. Nilai probabilitas lebih kecil dari 0,05 maka $\mathrm{H}_{0}$ ditolak dan diterima $\mathrm{H}_{\mathrm{a}}$ artinya hasil belajar materi tematik dalam penerapan model pembelajaran Make $A$ Match berbantuan puzzle lebih unggul daripada model pembelajaran Card Sort. Hasil hipotesis menunjukkan bahwa Ho ditolak, hasil rata-rata nilai posttest eksperimen 1 lebih tinggi dari posttest eksperimen 2 mendukunghasil uji hipotesis yang menyatakan adanya perbedaan hasil signifikan.Data komparasi nilai posttest eksperimen 1 adalah 81,22 sedangkan rata-ratanilai posttest eksperimen 2 adalah 74,50.
\end{abstract}

\begin{abstract}
The purpose of this study was to knowing the effectiveness of Make a Match and Card Sort learnng models with assisted puzzle reviewed from the $4^{\text {th }}$ graders of primary school learning outcome in Diponegoro's Cluster. The technique used in this study was quasi experimental.the sig. (2-tailed) was 0,022 and the sig. (1-tailed) was 0,0105 and tcount were 2,328. the Propability were smaller than 0,05 so $H_{0}$ was rejected and $H_{a}$ were accepted, it means learning outcome in thematic topic using Make A Match with assisted puzzle learning model was higher than using Card Sort learning model. Hypotheses result showed that Ho is rejected, the average of first experimental class posttest is higher than the second experimental class support the hypotheses test which explained that there were a significant differences. Comparation posttest's values in first experimental class were 81,22 and then the second experimental class were 74,50 .
\end{abstract}

\section{A. LATAR BELAKANG}

Permendikbud RI nomor 20 tahun 2016 tentang Kompetensi Inti dan Kompetensi Dasar Pelajaran Kurikulum 2013 Pada pendidikan Dasar dan Menengah menyatakan bahwa pelaksanaan pembelajaran pada Sekolah Dasar/Madrasah Ibtidaiyah (SD/MI) dilakukan dengan pendekatan pembelajaran tematikterpadu. Prastowo (2013: 223) menjelaskanpembelajaran tematik terpadu merupakan pendekatan pembelajaran yang mengintegrasikan berbagai kompetensi dari berbagai mata pelajaran ke dalam berbagai tema. Pengintegrasian tersebut dilakukan dalam dua hal, yaitu integrasi sikap, keterampilan, dan pengetahuan dalam proses pembelajaran dan integrasi berbagai konsep dasar yang berkaitan.

Berdasarkan hasil observasi, guru menggunakan model pembelajaran konvensional. Guru perlu melakukan inovasi pembelajaran yang dikolaborasikan dengan model - model pembelajaran agar siswa terlibat aktif dan semangat dalam mengikuti proses pembelajaran, sehingga membangkitkan motivasi belajar dan tujuan pembelajaran dapat tercapai.

Salah satu model pembelajaran yang dapat melibatkan siswa untuk berperan secara aktif adalah Model pembelajaran Make a Match. Nur Safitri (dalam Nadjamudin,1999) menyatakan, Make A-Match merupakan salah satu tipe pembelajaran kooperatif. Model Make AMatch adalah bentuk pengajaran dengan melalui cara mencari pasangan kartu yang dimiliki dan pasangan bisa dalam bentuk orang perorang apabila jumlah siswa banyak, kemudian berhadapan untuk saling menjelaskan makna kartu yang dimiliki. Dalam pembelajaran teknik make a-match terdapat unsur pencocokan kartu yang dimiliki dengan kartu lain yang sesuai.Melalui model Make a Match dapat menumbuhkan pemahaman siswa terhadap materi yang dipelajari serta dapat meningkatkan motivasi belajar siswa Miftahul Huda (2013: 253).

Model lain yang dapat digunakan guru adalah model pembelajaran Card Sort. Model pembelajaran aktif card sort merupakan kegiatan pembelajaran dengan cara memilih kartu sesuai kategori. Model pembelajaran ini 
bisa digunakan untuk mengajarkan konsep, karakteristik, klasifikasi, fakta, tentang obyek atau mereview informasi (Khoirunnisa, 2010). Model ini memberikan kesempatan kepada siswa untuk terlibat aktif dalam proses pendidikan. Keterlibatan ini berupa aktivitas belajar yang tidak hanya mendengar tetapi juga beraktivitas (Silberman, 2009:157)

Berdasarkan penelitian yang dilakukan oleh Pt.Mas Suatnaya.Ign I Wyn.Suatra.Wyn.Suarjana(2015), hasil penelitian menunjukkan bahwa terdapat perbedaan hasil belajar melalui penerapan model pembelajaran make a match dibandingkan dengan penerapan model pembelajaran konvensional. Kemudian penelitian yang dilakukan Kd.Meta Dewi, I Md.Putra,IB. Surya Manuaba(2013), menyatakan bahwa terdapat perbedaanyang signifikan hasil belajar IPS antara siswa yang dibelajarkan dengan menerapkan model pembelajaran kooperatif tipe make a match berbantuan media grafis dan siswa yang dibelajarkan dengan model pembelajaran konvensional pada siswa kelas V SDN 18 Pemecutan Tahun Pelajaran 2013/2014. Penelitian lain yang dilakukan oleh Ign I Wyn. Suwatra, I Gd. Robert Artawa(2013) yang disimpulkan bahwa pelaksanaan pembelajaran dengan menggunakan model pembelajaran kooperatif tipe make a-match pada pelajaran Matematika dapat memberikan pengaruh.

Penerapan Model Card Sort yang diteliti oleh Anggayuni, Weti, Marli, yang menunjukkan bahwa model pembelajaran aktif card sortdari hasil analisa diperoleh hasil thitung $=2,636$ pada tahap signifikan $\mathrm{a}=5 \%$ diperoleh $\mathrm{t}$ tabel $=1,995$, ternyata thitung $>\mathrm{t}$ tabel $(2,636>1,995)$ berarti signifikan, maka dapat disimpulkan bahwa model pembelajaran kooperatif Card Sort berpengaruh terhadap hasil belajar IPS siswa kelas IV. Kemudian penelitian yang dilakukan oleh Hidayati Azkiya(2017) pembelajaran Keterampilan Bersastra ke SD-an mahasiswa yang mengikuti pembelajaran menggunakan model pembelajaran aktif tipe card sort lebih tinggi dari pada mahasiswa yang mengikuti pembelajaran konvensional. Ditemukan pula penelitian lain yang dilakukan oleh Nurul Aini, Slamet Santoso, Bowo Sugiharto(2013) yang menunjukkan bahwa bahwa terdapat perbedaan hasil belajar biologi pada ranah kognitif dan psikomotorik strategi pembelajaran aktif tipe Make A Match dan Card Sort.

Berdasarkan perbedaan hasil penelitian, penulis timbul keragu-raguan model manakah yang lebih efektif diterapkan ditinjau dari hasil belajar siswa. Penulis mencoba menerapkan model make a match dan card sort berbantuan media puzzle. Penulis mencoba menggunakan media puzzle untuk membedakan dengan penelitian sebelumnya. Puzzle atau dengan nama lain disebut bagan balik yang merupakan kumpulan ringkasan, skema, gambar, tabel yang dibuka secara berurutan berdasarkan topik materi pembelajaran.Dengan menggunakan media Puzzledalam proses pembelajaran, diharapkan pembelajaran berlangsung lebih menarik dan menyenangkan, puzzle dapat mempermudah mengingat suatu materi pelajaran yang di ajarkan guru.

\section{Hakikat Tematik}

Permendikbud RI nomor 57 tahun 2014 tentang Kurikulum 2013 Sekolah Dasar/Madrasah Ibtidaiyah menyatakan bahwa pelaksanaan pembelajaran pada Sekolah Dasar/Madrasah dilakukan dengan pendekatan pembelajaran tematik-terpadu. Prastowo (2013: 223) menjelaskan pembelajaran tematik terpadu merupakan pendekatan pembelajaran yang mengintegrasikan berbagai kompetensi dari berbagai mata pelajaran ke dalam berbagai tema. Pengintegrasian tersebut dilakukan dalam dua hal, yaitu integrasi sikap, keterampilan, dan pengetahuan dalam proses pembelajaran dan integrasi berbagai konsep dasar yang berkaitan

Oemar Hamalik (2011: 158) menyatakan bahwa kurikulum terintegrasi atau terpadu (integrated curriculum), batas-batas diantara semua mata pelajaran sudah tidak terlihat sama sekali. Semua mata pelajaran sudah dirumuskan dalam bentuk masalah atau unit. Unit atau yang disebut tema dalam kurikulum 2013 terdiri dari beberapa subtema yang berisi beberapa mata pelajaran antara lain Bahasa Indonesia, IPA, PPKn, dan IPS.

M Fadillah (2014: 176) pembelajaran tematik terintegrasi dimaksudkan bahwa pembelajaran tersebut dibuat per tema dengan mengacu karakteristik peserta didik dan dilaksanakan secara terintegrasi antara tema satu dengan yang lain maupun antara mata pelajaran satu dengan mata pelajaran yang lain. Salah satu materi di kelas IV pada materi Tema 8 Sub Tema Daerah Tempat Tinggalku.Pada sub tema 2 mata pelajaran yang terkandung di dalamnya adalah PPKn, Bahasa Indonesia, SBdP, IPS, dan IPA yang di dalamnya terdapat berbagai macam materi pembelajaran yang membutuhkan ingatan dan pemahaman

Pembelajaran merupakan suatu kegiatan belajar mengajar yang tidak terlepas dengan aktivitas dan interaksi antara guru dengan siswa. Interaksi yang terjalin antara guru dan siswa bernilai edukatif, dikarenakan kegiatan belajar mengajar yang dilakukan mengarah pada pencapaian tujuan tertentu yang telah dirumuskan sebelum dilaksanakannya pengajaran. Guru dengan sadar merancang kegiatan pengajarannya secara sistematis dengan memanfaatkan segala sesuatunya untuk kepentingan pengajaran

Salah satu kegiatan yang perlu dilaksanakan dalam pendidikan adalah evaluasi. Evaluasidalam pendidikan dilaksanakan untuk memperoleh informasi tentang aspek yang berkaitandengan pendidikan. Terwujudnya pendidikanyang bermutu membutuhkan upaya yang terus menerus untuk selalu meningkatkan kualitaspendidikan. Peningkatan kualitas pendidikan memerlukan upaya peningkatan kualitaspembelajaran 
karena muara dari berbagai program pendidikan adalah pada terlaksananyaprogram pembelajaran yang berkualitas. Oleh karena itu peningkatan kualitas pendidikan tidakakan tercapai tanpa adanya keberhasilan dari pembelajaran yang dilaksanakan.

Untuk mengetahui keberhasilan pendidikan secara umum dan pembelajaran padakhususnya, perlu dilakukan asesmen pendidikan atau terminology umumnya sering disebutdengan evaluasi pendidikan. Dalam kaitannya dengan pendidikan, UU nomor 20 tahun 2003tentang Sisdiknas pasal 1 ayat 21 menyatakan bahwa evaluasi pendidikan adalah kegiatanpengendalian, penjaminan, dan penetapan mutu pendidikan terhadap berbagai komponenpendidikan pada setiap jalur, jenjang, dan jenis pendidikan sebagai bentuk pertanggungjawabanpenyelenggaraan pendidikan.

\section{Model Pembelajaran Kooperatif}

Peran guru sangat penting dalam membantu peserta didik dalam rangka memahami pembelajaran. Guru harus pandai - pandai menwujudkan suasana belajar yang kreatif untuk dapat meminimalisir persoalan yang akan muncul di dalam kelas, guru juga perlu memperhatikan perubahan yang muncul akibat dari suatu persoalan yang timbul, serta mampu mencari jalan keluar dari permasalahan tersebut. Pesatnya perkembangan dalam bidang pendidikan saat ini, memunculkan ide para ahli untuk merancang model dan metode pembelajaran agar dapat dijadikan pedoman pendidik untuk meningkatkan hasil belajar peserta didik.

Pembelajaran kooperatif dapat menciptakan hubungan baik antara pendidik dan siswa di dalam proses pembelajaran. Sikap berfikir kritis dan kemampuan siswa di dalam menyelesaikan suatu permasalahan dalam kelompok serta membantu mempermudah pendidik dalam menyampaikan materi pelajaran, merupakan tujuan diterapkannya pembelajaran kooperatif.

Salah satu model pembelajaran yang membentuk siswa ke dalam kelompok - kelompok, memiliki karakteristik yang berbeda dalam tingkat berfikirnya ada siswa yang memiliki tingkat berfikir tinggi, sedang, maupun rendah. Model kooperatif ini mengutamakan pembentukkan kelompok agar terjadi interaksi secara langsung antara siswa satu dan yang lainnya untuk menyelesaikan permasalahan yang dihadapi, peserta didik juga diharapkan mampu mengaplikasikan pengetahuan dan keterampilannya dalam rangka mencapai tujuan pembelajaran.

Daryanto dan Muljo (2012: 241) mengatakan bahwa :' Model pembelajaran kooperatif ini adalah model yang mengutamakan adanya kelompok. Pembentukkan kelompok yang di dalamnya terdiri dari siswa siswi yang memiliki perbedaan baik ras, budaya, suku yang berbeda serta memperhatikan kesetaraan gender." Pembelajaran kooperatif dapat pula diartikan struktur tugas bersama dalam suasana kebersamaan diantara kebersamaan tiap anggota kelompok.

\section{Model Pembelajaran Make a Match}

Rusman (2011: 223) menjelaskan model make a match (membuat pasangan) merupakan salah satu jenis dari model dalam pembelajaran kooperatif. Ini berarti bahwa dalam proses pembelajaran dilakukan bersama kelompok.Miftahul Huda (2015: 251) menjelaskan bahwa tujuan dari make a match antara lain (1) pendalaman materi, (2) penggalian materi, dan (3) edutainment.

Langkah model make a match menurut Miftahul Huda (2015: 252) adalah sebagai berikut:1) Guru menyampaikan materi atau memberi tugas kepada siswa untuk mempelajari materi di rumah. 2) Siswa dibagi ke dalam 2 kelompok, misalnya kelompok A dan B. Kedua kelompok diminta berhadap-hadapan. 3) Guru membagikan kartu pertanyaan kepada kelompok A dan kartu jawaban kepada kelompok B. 4) Guru menyampaikan kepada siswa bahwa mereka harus mencari/mencocokkan kartu yang dipegang dengan kartu kelompok lain. Guru juga perlu menyampaikan batasan maksimum waktu yang ia berikan kepada mereka. 5) Guru meminta semua anggota kelompok A untuk mencari pasangannya di kelompok B. Jika mereka sudah menemukan pasangannya masing-masing, guru meminta mereka melaporkan diri kepadanya. Guru mencatat mereka pada kertas yang sudah disiapkan. 6) Jika waktu sudah habis, mereka harus diberitahu bahwa waktu sudah habis. Siswa yang belum menemukan pasangan diminta untuk berkumpul tersendiri. 7)Guru memanggil satu pasangan untuk presentasi. Pasangan lain dan siswa yang tidak mendapat pasangan memperhatikan dan memberi tanggapan apakah pasangan kartu soal dan kartu jawaban tersebut cocok atau tidak. 8) Terakhir guru memberikan konfirmasi tentang kebenaran dan kecocokan pertanyaan dan jawaban dari pasangan yang memberikan presentasi. Kemudian guru memanggil pasangan berikutnya, begitu seterusnya sampai seluruh pasangan melakukan presentasi.

\section{Model Pembelajaran Card Sort}

Card Sort didukung oleh penyajian data yang diawali dengan pemberian kartu kepada siswa. Di dalam kartu ada catatan yang harus dikuasai atau dihafal masingmasing siswa. Siswa kemudian mencari pasangannya masing-masinguntuk bertukar pengetahuan sesuai dengan apa yang didapatnya dikartu, lalu kegiatan pembelajaran diakhiri dengan mengevaluasi siswa dengan menanyakan pengetahuan yang mereka miliki dan pengetahuan yang mereka terima dari pasangannya (Huda, 2013: 242).

Kurniasih dan Berlin Sani (2015: 103) menjelaskan bahwa kelebihan model pembelajaran Card Sort yaitu dapat dimodifikasi sedemikian rupa sesuai dengan keinginan dan situasi pembelajaran, melatih siswa untuk 
bekerja sama dan menghargai kemampuan orang lain, melatih siswa untuk berinteraksi secara baik dengan teman sekelas, memperdalam dan mempertajam pengetahuan siswa melalui kartu yang dibagikan, meningkatkan tanggung jawab siswa, sebab masingmasing siswa dibebani pertanggungjawaban atas kartunya masing-masing.

Kurniasih dan Berlin Sani (2015: 103) juga mengemukakan bahwa kekurangan Card Sort adalahkesulitan untuk mendisiplinkan siswa dalam kelompok-kelompok, ketidaksesuaian skill antara siswa yang memiliki kemampuan akademik yang baik dan siswa yang kurang memiliki kemampuan akademik, kecenderungan terjadinya free riders dalam setiap kelompok, utamanya siswa-siswa yang akrab satu sama lain.

Langkah-langkah pembelajaran dengan Card Sort menurut Miftahul Huda (2013: 242) adalah sebagai berikut: 1) Guru mempersiapkan kartu yang akan digunakan dalam proses pembelajaran dan mendesain kelas sebagaimana mestinya. 2) Guru menjelaskan materi sesuai dengan kompetensi yang ingin dicapai. 3) Untuk memantapkan penguasaan siswa, mereka diberi masing-masing satu kartu untuk dipelajari atau dihafal. 4) Semua siswa disuruh berdiri dan mencari pasangan untuk saling memberi informasi. Tiap siswa harus mencatat nama pasangannya pada kartu yang dipegangnya. Demikian seterusnya hingga setiap siswa dapat saling memberi dan menerima materi masingmasing. 5)Untuk mengevaluasi keberhasilan siswa, guru dianjurkan memberi pertanyaan yang tidak sesuai dengan kartu. Strategi ini dapat dimodifikasi sesuai dengan keadaan. 6) Guru menutup pembelajaran.

\section{Media Pembelajaran}

Asosiasi Pendidikan Nasional memiliki pengertian media yang berbeda. Media merupakan bentuk komunikasi baik tercetak maupun audiovisual serta peralatannya (Sadiman dkk, 2014: 6-7).

Media yang digunakan dalam penelitian ini yaitu media puzzle. Media puzzle termasuk jenis media grafis karena media puzzle merupakan media kartu bergambar yang menyalurkan pesan melalui indera penglihatan.

Indriana (2011: 67-69) menjelaskan bahwa media puzzle merupakan media kartu bergambar yang berukuran $25 \mathrm{~cm} \times 30 \mathrm{~cm}$ dan berupa tampilan gambar yang penuh dengan warna dan dapat menarik perhatian anak. Gambar yang ditampilkan dalam media puzzle dapat berupa gambar tangan, foto, atau gambar yang sudah ada ditempelkan pada puzzle Kelebihan dari media puzzle yaitu mudah dibawa kemana-kemana, praktis dalam pembuatan dan penggunaannya.

\section{Hasil Belajar}

Hasil belajar merupakan perubahan perilaku yang diperoleh siswa setelah mengalami kegiatan pembelajaran. Perolehan aspek-aspek perubahan perilaku tersebut tergantung pada apa yang dipelajari oleh siswa.Hasil belajar diperoleh siswa secara menyeluruh (komprehensif) yang mencakup ranah kognitif, ranah afektif, dan ranah psikomotorik (Sudjana, 2005: 57).Penilaian aspek sikap dilakukan melalui observasi atau pengamatan, penilaian aspek pengetahuan dilakukan melalui tes tertulis, tes lisan, dan penugasan, penilaian aspek keterampilan dilakukan melalui praktik, produk, proyek, dan portofolio.

Penilaian hasil belajar dilakukan melalui tes tertulis, tes lisan, penugasan, observasi, praktik, produk, proyek, dan portofolio. Hasil belajar dari seorang siswa juga dipengaruhi oleh factor internal dan faktor ekternal. Berdasarkan hasil belajar, dapat diketahui tercapai atau tidaknya tujuan dari kegiatan pembelajaran. Hasil belajar dalam penelitian ini adalah hasil belajar kognitif dari siswa dalam pembelajaran tematik.

\section{Hasil Penelitian Relevan}

Kajian penelitian relevan penerapan model pembelajaran make a matchdan card sort, penelitian yang dilakukan oleh Pt. Edy Pariawan, DB. Kt. Ngr. Semara Putra, dan IB. Gd Surya Abadi (2013) menunjukkan bahwa terdapat perbedaan yang signifikan antara penerapan model pembelajaran make a match dan model pembelajaran konvensional, penerapan model pembelajaran card sort memberikan pengaruh terhadap hasil belajar IPS siswa kelas 5 SD. Selanjutnya penelitian yang dilakukan oleh Ni L. G. Mega Puspita Dewi, IGA.A. Sri Asri, dan I Km. Ngurah Wiyasa (2014), hasil penelitian menunjukkan bahwa rata-rata hasil belajar PKn kelompok siswa yang mengikuti pembelajaran menggunakan model pembelajaran make a match berbantuan media grafis lebih besar dari kelompok siswa yang mengikuti pembelajaran konvensional. Kemudian penelitian yang dilakukan oleh N. L. G. Sri Yuliastini, I Dewa Kade Tastra, dan I Wyn Romi Sudhita (2015) hasil penelitian menunjukkan bahwa rata-rata hasil belajar IPS lebih tinggi dengan menggunakan model pembelajaran card sort dibandingkan dengan model pembelajaran konvensional.

Beberapa hasil penelitian juga menunjukkan keampuhan penerapan model pembelajaran make a match. Penelitian yang dilakukan oleh Ni Kd. Eka Mariani, I Wyn. Wiarta, dan I Md. Suara (2014) menunjukkan bahwa terdapat perbedaan yang signifikan antara penerapan model pembelajaran make a match dan model pembelajaran konvensional. Hasil belajar matematika siswa kelas 5 SD lebih tinggi menggunakan model pembelajaran make a match dibandingkan dengan menggunakan model pembelajaran konvensional. Selanjutnya penelitian yang dilakukan oleh Khoirulmuna Dyah Subekti (2015) hasil penelitian menunjukkan bahwa prestasi belajar matematika siswa yang mendapatkan model pembelajaran make a match lebih baik dibandingkan dengan yang mendapatkan model pembelajaran snowball throwing pada siswa kelas VII MTs. Penelitian lain yang dilakukan oleh Nofrita Mauliza Hayati, Abu Syafik, dan Puji Nugraheni (2014) hasil penelitian menunjukkan bahwa model pembelajaran make a match tidak menghasilkan prestasi belajar matematika yang lebih baik daripada model pembelajaran konvensional. Kemudian penelitian yang dilakukan oleh Nurlia Astika dan Ngurah Ayu Nyoman M, hasil penelitian menunjukkan bahwa model pembelajaran kooperatif tipe make a match lebih efektif meningkatkan hasil belajar siswa bila dibandingkan dengan model pembelajaran konvensional.

Berbagai hasil penelitian menunjukkan keampuhan penerapan model card sort jika dibandingkan dengan model pembelajaran konvensional, begitupula dengan model pembelajaran make a match yang juga ampuh jika dibandingkan dengan model pembelajaran 
konvensional atau model pembelajaran lain. Penelitian yang dilakukan oleh Heti Podomi (2012) hasil penelitian menunjukkan bahwa hasil belajar siswa dengan menggunakan model pembelajaran make a match lebih baik daripada siswa yang diajarkan melalui model pembelajaran card sort pada materi ekosistem.

\section{B. METODE PENELITIAN}

Penelitian ini menggunakan jenis penelitian kuasi eksperimen. Penelitian kuasi eksperimen adalah satu satunya metoda penelitian yang benar - benar dapat digunakan untuk menguji hipotesis sebab akibat yang di dalamnya menyajikan pendekatan yang paling valid untuk menyelesaikan masalah pendidikan. Dalam penelitian ini variabel - variabel yang ada termasuk variabel bebas atau independent variabel dan variabel terikat dependent variabel, sudah ditentukan secara tegas oleh penyusun sejak awal melakukan penelitian (Hamid Harmadi, (2011:175).

Slameto(2015: 137) berpandangan bahwa penelitian eksperimen kuasi merupakan penelitian yang mendekati penelitian sungguhan, namun tidak dapat mengontrol smeua variabel yang ada. Pandangan serupa juga dikemukakan oleh Sugiono(2014:116) bahwa bentuk desain ini ialah pengembangan dari true experimental design, yang sulit dilaksanakan, kelompok kontrol yang dimiliki dalam desain ini tidak sepenuhnya mampu mengontrol variabel luar yang mempengaruhi pelaksanaan eksperimen.

Dapat ditarik kesimpulan bahwa pandangan Slameto(2015: 42) dan Sugiono(2014: 89) bahwa eksperimen kuasi merupakan jenis penelitian yang dapat digunakan apabila terdapat kesulitan ketika melakukan kontrol terhadap variabel.

Pengambilan sampel yang digunakan dalam penelitian ini adalah teknik probability sampling jenis cluster sampling (area sampling). Sampel yang digunakan dalam penelitian ini, yaitu SD Mangunsari o1 sebagai SD inti dengan jumlah siswa 40, SD Mangunsari o5 sebagai SD imbas dekat dengan jumlah siswa 40, dan SD Mangunsari o6 sebagai SD imbas jauh dengan jumlah siswa 21.

Jenis instrumen yang digunakan dalam mengumpulkan data yaitu tes dan nontes. Instrumen yang digunakan dalam teknik tes yaitu lembar pretest dan posttest berupa pilihan ganda, sedangkan instrumen yang digunakan pada teknik nontes adalahlembar observasi.

\section{HASIL DAN PEMBAHASAN}

Penelitian ini menggunakan desain Nonequivalent Control Group Design. Berikut gambaran lebih rinci dari desain penelitian Nonequivalent Control Group Design.

TABEL 1

DESAIN PENELITIAN NONEQUIVALENT CONTROL GROUP DESIGN

\begin{tabular}{|l|c|c|c|}
\hline Kelompok & $\begin{array}{c}\text { Sebelum } \\
\text { Perlakuan }\end{array}$ & Perlakuan & $\begin{array}{c}\text { Sesudah } \\
\text { Perlakuan }\end{array}$ \\
\hline $\begin{array}{l}\text { Kelompok } \\
\text { Eksperimen }\end{array}$ & $\mathrm{O}_{1}$ & $\mathrm{X}_{1}$ & $\mathrm{O}_{2}$ \\
1 & & & \\
\hline $\begin{array}{l}\text { Kelompok } \\
\text { Eksperimen } \\
2\end{array}$ & $\mathrm{O}_{3}$ & $\mathrm{X}_{2}$ & $\mathrm{O}_{4}$ \\
\hline
\end{tabular}

Keterangan :

$\mathrm{X}_{1} \quad$ : Perlakuan 1(pembelajaran menggunakan model Make a Match)

$\mathrm{X}_{2} \quad$ : Perlakuan 2(pembelajaran menggunakan model Card Sort)

$\mathrm{O}_{1} \quad$ : Hasil pretest kelompok eksperimen 1

$\mathrm{O}_{2} \quad$ : Hasil postest kelompok eksperimen 1

$\mathrm{O}_{3} \quad$ : Hasil pretest kelompok eksperimen 2

$\mathrm{O}_{4} \quad$ : Hasil postest kelompok eksperimen 2

Penelitian dengan menggunakan model Make a Match dan Card Sort berbantuan media Puzzle ini diuji cobakan di SD Gugus Diponegoro Sidomukti Salatiga kelas 4 Semester II Tahun Pelajaran 2017/2018. Populasi penelitian ini adalah seluruh siswa kelas 4 Gugus Diponegoro. Populasi penelitiannya adalah seluruh siswa kelas 4 Gugus Diponegoro Sidomukti Salatiga, sedangkan yang menjadi sampel penelitian yaitu 101 siswa SD Mangunsari 01, SD Mangunsari 05, dan SD Mangunsari o6

Pengumpulan data pada penelitian ini menggunakan instrumen soal tes yang di dalamnya terdapat soal pre test dan post test dengan bentuk soal tes pilihan ganda serta menggunakan lembar observasi untuk mengetahui aktivitas guru dan siswa dalam proses pembelajaran , untuk mengetahui terlaksananya sintak atau belum.

Penelitian ini dilakukan menggunakan variabelbebas(X) dan variabel terikat $(\mathrm{Y})$. Variabel bebas menggunakan model pembelajaran Make a Match (X1) berbantuan puzzle dan Card Sort (X2) berbantuan puzzle. Sedangkan variabel terikat dalam penelitian ini adalah hasi 1 belajar Tema 8 Sub Tema 2 Pembelajaran 4, yaitu hasil belajar siswa yang diperoleh melalui pembelajaran dengan model Make a Match (Y1) dan hasil belajar matematika siswa diperoleh melalui pembelajaran dengan menggunakan model Card Sort(Y2).

\section{Tingkat Hasil Belajar Tematik Siswa kelas 4 SD di Gugus Diponegoro dengan menggunakan Make a Match sebagai Kelompok Eksperimen/ Eksperimen 1}

Tingkat hasil belajar tematik siswa kelas 4 SD di Gugus Diponegoro dengan menggunakan model pembelajaran Make a Match dipaparkan melalui statistik deskriptif dari hasil pretest dan posttest ang terdiri dari rata-rata, nilai tertinggi, nilai terendah, dan standar deviasi

TABEL 2

STATISTIK DESKRIPTIF NILAI PRETEST DAN POSTTEST KELOMPOK EKSPERIMEN 1

\begin{tabular}{|c|c|c|c|c|c|}
\hline & $\mathrm{N}$ & Min & Max & Mean & \begin{tabular}{|l} 
Std. \\
Deviation
\end{tabular} \\
\hline $\begin{array}{ll}\text { Pretest } & \\
\text { Postest } & \\
\text { Valid } & \mathrm{N} \\
\text { (listwise) } & \end{array}$ & $\begin{array}{l}45 \\
45 \\
45\end{array}$ & $\begin{array}{l}25 \\
50\end{array}$ & $\begin{array}{l}95 \\
100\end{array}$ & $\begin{array}{l}66,1111 \\
81,2222\end{array}$ & \begin{tabular}{|l|}
17,57739 \\
13,19244
\end{tabular} \\
\hline
\end{tabular}

Berdasarkan tabel 2 di atas nilai rata - rata pre test kelas ekperimen 1 sebelum proses pembelajaran diberikan perlakuan menggunakan model Make a Match berbantuan Puzzle sebesar 66,11 dengan 
standar deviasi 17,57739. Sedangkan setelah diberikan perlakuan menggunakan model kooperatif tipe Make a Match Berbantuan Puzzle didapatkan nilai rata - rata posttest meningkat menjadi 81,2222 dengan standar deviasi 13, 19244. Selain itu dapat kita lihat juga nilai tertinggi yang tercapai pada pre test adalah 95 dan nilai terendahnya adalah 25 . Sedangkan pada posttest nilai yang berhasil dicapai adalah 100 dan nilai terendahnya adalah 50.

2. Tingkat Hasil Belajar Tema 8 Sub Tema 2 Pembelajaran 3 Siswa kelas 4 SD Mangunsari o1 dengan Menggunakan Model Pembelajaran Card Sort sebagai Kelompok Kontrol/Eksperimen 2

Tingkat hasil belajar siswa tema 8 sub tema 4 pembelajaran 3 kelas 4 SD di Gugus Diponegoro dengan menggunakan model pembelajaran Card Sort dipaparkan melalui statistik deskriptif dari hasil pretest dan posttest ang terdiri dari rata-rata, nilai tertinggi, nilai terendah, dan standar deviasi. Berikut tabel statistik deskriptif nilai Pretest dan Posttest Kelompok Eksperimen 2.

\section{TABEL 3}

STATISTIK DESKRIPTIF NILAI PRETEST DAN POSTTEST KELOMPOK EKSPERIMEN 2

\begin{tabular}{|l|l|l|l|l|l|}
\hline & N & Min & Max & Mean & $\begin{array}{l}\text { Std. } \\
\text { Deviation }\end{array}$ \\
\hline PRE_CS & 50 & 20 & 100 & 65,5000 & 17,85000 \\
POST_CS & 50 & 25 & 100 & 74,5000 & 14,78589 \\
$\begin{array}{l}\text { Valid N } \\
\text { (listwise) }\end{array}$ & 50 & & & & \\
\hline
\end{tabular}

Berdasarkan tabel 4.4 di atas tampak bahwa nilai rata - rata pretest kelas eksperimen 2 sebelum diberikan perlakuan menggunakan model kooperatif tipe Card Sort berbantuan dengan media puzzle sebesar 65,5 dengan standar deviasi 17,85000. Sedangkan setelah diberikan perlakuan menggunakan model Card Sort Berbantuan media puzzle kelas nilai rata - rata yang didapatkan ketika posttest adalah 74,5 dengan standar deviasi 14,78589 . Dari tabel di atas tampak nilai tertinggi yang tercapai pada pretest 100, dan nilai terendahnya adalah 20 . Sedangkan dapat kita lihat pula, bahwa nilai posttest nilai tertingginya adalah 100 , dan nilai terendahnya adalah 25 .

\section{Deskripsi Komparasi Hasil Pengukuran}

Deskripsi komparasi dalam penelitian ini memaparkan perbedaan hashil pengukuran dari kelompok eksperimen 1 dan eksperimen 2 berdasarkan nilai pretest dan nilai posttest. Deskripsi komparasi disajikan dalam bentuk tabel dan grafik berikut.
TABEL 4

TABEL KOMPARASI HASHIL PENGUKURAN KELOMPOK EKSPERIMEN 1 DAN EKSPERIMEN 2 SD GUGUS DIPONEGORO

\begin{tabular}{|l|l|l|l|}
\hline \multirow{2}{*}{$\begin{array}{c}\text { Tahap } \\
\text { Pengukuran }\end{array}$} & \multicolumn{2}{|c|}{ Rata-rata kelompok } & \multirow{2}{*}{$\begin{array}{c}\text { Selisih } \\
\text { skor }\end{array}$} \\
\cline { 2 - 4 } & $\begin{array}{c}\text { Eksperimen } \\
\mathbf{1}\end{array}$ & $\begin{array}{c}\text { Eksperimen } \\
\mathbf{2}\end{array}$ & \\
\hline Pretest & 66,1111 & 81,2222 & $\mathbf{1 5 , 1 1 1 1}$ \\
\hline Posttest & 65,5000 & 74,5000 & 9 \\
\hline
\end{tabular}

Dari tabel 4 di atas tampak perbedaan nilai rata - rata tahap pengukuran awal ditunjukkan selisih akor antara kelompok eksperimen 1 dan kelompok ekperimen 2 sebesar 15,1111dimana rata - rata eksperimen 1 lebih unggul. Secara ringkas deskripsi komparasi hasil pengukuran dapat dilihat melalui grafik di bawah ini :

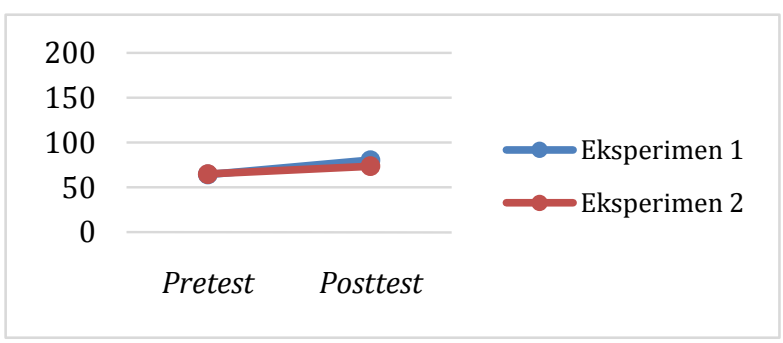

Gambar 1. Deskripsi Komparasi

\section{Hasil Uji Perbedaan Rerata Hasil Belajar Menggunakan Model}

Setelah uji prasyarat terpenuhi (uji normalitas data dan homogenitas) selanjutnya dilakukan uji beda rata-rata nilai posttest. Berikut akan disajikan hasil uji beda rata-rata (Uji T).

TABEL 5

HASIL UJI T NILAI POSTTEST KELOMPOK EKSPERIMEN 1 DAN EKSPERIMEN 2

\begin{tabular}{|l|l|l|l|l|}
\hline \multicolumn{4}{|l|}{$\begin{array}{l}\text { Levene's Test for } \\
\text { Equality of Variances }\end{array}$} & \multicolumn{1}{l|}{$\begin{array}{l}\text { t-test for } \\
\text { Means }\end{array}$} \\
\hline F & Sig. & T & Df & $\begin{array}{l}\text { Sig. (2- } \\
\text { tailed) }\end{array}$ \\
\hline, 107 &, 744 & 2,328 & 93 &, 022 \\
\hline
\end{tabular}

Berdasarkan tabel 5 analisis Uji Beda $\mathrm{T}$ menggunakan equal variances assumed(asumsi varian sama) dari tabel $4.11 \mathrm{di}$ atas dapat terlihat bahwa nilai t hitung adalah 2,342 dengan sig(2-tailed) 0,022 dan sig(1-tailed) 0,011 dan df 93, sehingga dapat terlihat tabel 1,646.Nilai probablilitas < o,05 maka $\mathrm{H}_{0}$ ditolak dan $\mathrm{H}_{\mathrm{a}}$ diterima, dapat dikatakan juga bahwa hasil belajar kelompok eksperimen 1 yaitu Make a Match lebih tinggi daripada kelompok eksperimen 2 yaitu Card Sort.

\section{Pembahasan}

Penelitian telah dilakukan di SD Gugus Diponegoro Kecamatan Sidomukti Yaitu SD Mangunsari 01, SD Mangunsari 05, dan SD Mangunsari o6. Pada masing - masing SD ada 2 
kelas yaitu kelas 4A dan 4B, untuk kelas A sebagai kelas eksperimen 1 dengan melaksanakan kegiatan pembelajaran menggunakan model Make a Match Berbantuan Puzzle dan kelas 4B sebagai kelas eksperimen 2 dengan melaksanakan pembelajaran menggunakan model Card Sort Berbantuan Puzzle berjalan lancar sesuai dengan sintak dan Rencana Pelaksanaan Pembelajaran.

Perolehan analisis deskriptif kelompok eksperimen 1 dapat dilihat dari hasil pretest sebesar 66,1111 meningkat menjadi 655,00o dilihat dari hasil nilai posttest. Sedangkan pada kelompok eksperimen 2 juga mengalami peningkatan yaitu perolehan skor pretest sebesar 65,5000 dan hasil posttest sebesar 74,5000 .

Analisis atau uji beda (uji $\mathrm{T}$ ) dengan nilai $\mathrm{t}$ hitung adalah 2,342 dengan sig. (2-tailed) 0,021 dan sig. (1-tailed) 0,0111 dan df sebesar 93 sehingga didapat $\mathrm{t}$ tabel 1,684. Nilai probablilitas < 0,05 maka $\mathrm{H}_{\mathrm{o}}$ ditolak dan $\mathrm{H}_{\mathrm{a}}$ diterima, dapat dikatakan juga bahwa hasil belajar kelompok eksperimen 1 lebih tinggi daripada kelompok eksperimen 2. Berdasarkan hasil dari uji hipotesis yang menggunakan analisis uji beda (uji T) dapat dikatakan bahwa model pembelajaran Make a Match Berbantuan Puzzlelebih unggul secara signifikan daripada model pembelajaran Card Sort Berbantuan Puzzleyang ditinjau dari hasil belajar Tema 8 Sub Tema 2 Pembelajaran 3.

Dalam penerapan model Make a Match Berbantuan Puzzle lebih unggul dibandingkan Card Sort Berbantuan Puzzle. Model Pembelajaran Make a Match mempunyai sintak pembelajaran yang menarik, siswa memasangkan keping jawaban dengan papan soal, dengan media puzzle dan tentunya banyak digemari oleh anak - anak, dan mudah karenakeping jawaban dan soal sama jumlahnya, tidak perlu melalui tahapan menyortir. Berikut adalah sintak dari model Make a Match menurut Langkah model make a match menurut Miftahul Huda (2015: 252) adalah sebagai berikut: (1)Guru menyampaikan materi atau memberi tugas kepada siswa untuk mempelajari materi di rumah, (2)Siswa dibagi ke dalam 2 kelompok, misalnya kelompok A dan B. Kedua kelompok diminta berhadap-hadapan, (3)Guru membagikan kartu pertanyaan kepada kelompok A dan kartu jawaban kepada kelompok B,(4)Guru menyampaikan kepada siswa bahwa mereka harus mencari/mencocokkan kartu yang dipegang dengan kartu kelompok lain. Guru juga perlu menyampaikan batasan maksimum waktu yang ia berikan kepada mereka, (5)Guru meminta semua anggota kelompok A untuk mencari pasangannya di kelompok B. Jika mereka sudah menemukan pasangannya masing-masing, guru meminta mereka melaporkan diri kepadanya. Guru mencatat mereka pada kertas yang sudah disiapkan,
(6)Jika waktu sudah habis, mereka harus diberitahu bahwa waktu sudah habis. Siswa yang belum menemukan pasangan diminta untuk berkumpul tersendiri, (7)Guru memanggil satu pasangan untuk presentasi. Pasangan lain dan siswa yang tidak mendapat pasangan memperhatikan dan memberi tanggapan apakah pasangan kartu soal dan kartu jawaban tersebut cocok atau tidak, (8)Terakhirguru memberikan konfirmasi tentang kebenaran dan kecocokan pertanyaan dan jawaban dari pasangan yang memberikan presentasi. Kemudian guru memanggil pasangan berikutnya, begitu seterusnya sampai seluruh pasangan melakukan presentasi.

Model Pembelajaran Card Sort dengan dibandingkan Model Make a Match juga tidak kalah menarik dilihat dari hasil posttest dengan selisih 6 poin juga memiliki sintak pembelajaran yang hampir sama dengan model pembelajaran Card Sort, yakni sama-sama melakukan memasangkan kartu soal dan kartu jawaban. Langkah-langkah model pembelajaranCard Sort. Tahap pertama, guru mempersiapkan kartu yang akan digunakan untuk card sort. Tahap kedua, guru menjelaskan materi sesuai dengan kompetensi yang ingin dicapai. Tahap ketiga, siswa diberi masing-masing satu kartu untuk dipelajari atau dihafal untuk memantapkan penguasaan materi. Tahap keempat siswa mencari pasangan untuk saling memberi informasi, siswa dapat melakukannya dengan berdiri dan berkeliling kelas untuk bertukar informasi. Ketika bertukar informasi, tiap siswa harus mencatat nama pasangannya pada kartu yang dipegangnya. Demikian seterusnya hingga setiap siswa dapat saling memberi dan menerima materi masing-masing (card sort). Tahap kelima ialah evaluasi untuk mengevaluasi keberhasilan siswa, guru memberi pertanyaan yang tidak sesuai dengan kartu. Strategi ini dapat dimodifikasi sesuai dengan keadaan. Tahap keenam, guru menutup pembelajaran dengan memberikan tes tertulis kepada siswa.

Sependapat dengan hasil penelitian yang dilakukan oleh penelitian yang dilakukan oleh Nurlia Astika dan Ngurah Ayu Nyoman M, hasil penelitian menunjukkan bahwa model pembelajaran kooperatif tipe make a match lebih efektif meningkatkan hasil belajar.

Keampuhan Make a Match juga diperkuat oleh penelitian yang dilakukan penelitian yang dilakukan oleh Ni L. G. Mega Puspita Dewi, IGA.A. Sri Asri, dan I Km. Ngurah Wiyasa (2014), hasil penelitian menunjukkan bahwa rata-rata hasil belajar PKn kelompok siswa yang mengikuti pembelajaran menggunakan model pembelajaran make a match berbantuan media grafis lebih besar dari kelompok siswa yang mengikuti pembelajaran konvensional.Kajian penelitian relevan penerapan model pembelajaran make a match dan card sort, 
penelitian yang dilakukan oleh Pt. Edy Pariawan, DB. Kt. Ngr. Semara Putra, dan IB. Gd Surya Abadi (2013) menunjukkan bahwa terdapat perbedaan yang signifikan antara penerapan model pembelajaran make a match dan model pembelajaran konvensional, penerapan model pembelajaran card sort memberikan pengaruh terhadap hasil belajar IPS siswa kelas 5 SD. Selanjutnya penelitian yang dilakukan oleh Ni L. G. Mega Puspita Dewi, IGA.A. Sri Asri, dan I Km. Ngurah Wiyasa (2014), hasil penelitian menunjukkan bahwa rata-rata hasil belajar PKn kelompok siswa yang mengikuti pembelajaran menggunakan model pembelajaran make a match berbantuan media grafis lebih besar dari kelompok siswa yang mengikuti pembelajaran konvensional

Beberapa hasil penelitian juga menunjukkan keampuhan penerapan model pembelajaran make a match. Penelitian yang dilakukan oleh Ni Kd. Eka Mariani, I Wyn. Wiarta, dan I Md. Suara (2014) menunjukkan bahwa terdapat perbedaan yang signifikan antara penerapan model pembelajaran make a match dan model pembelajaran konvensional. Hasil belajar matematika siswa kelas 5 SD lebih tinggi menggunakan model pembelajaran make a match dibandingkan dengan menggunakan model pembelajaran konvensional. Selanjutnya penelitian yang dilakukan Ni Pt.Dayantari,Ndara Tanggu Renda, Ni Ngh.Madri Antari, Ni Made Suandayani Ari Putri, Ni Wayan Suniasih, I Wayan Wiarta, Kd. MetaDewi, I Md. Putra, I B. Surya Manuaba, Arfian Bobby Chandra, Hadi Mulyono, Chumdari, Amrih Setyowati, Suhartono, M.Chamdani, Siti Qodriyatun, Suhartono, Ngatman, I Gede Rudiksa Wiradnyana, I Made Tegeh, Syahruddin, I G. A. Ary anggarawati, MG. Rini Kristantari, I G A. Agung Sri Asri, I Kd. Adi Wiguna, Md Sumantri, Gd Raga yang membuktikan bahwa mode pembelajaran Make a match lebih tinggi secara signifikan terhadap model lain. Penelitian lain yang dilakukan oleh Nofrita Mauliza Hayati, Abu Syafik, dan Puji Nugraheni (2014) hasil penelitian menunjukkan bahwa model pembelajaran make a match tidak menghasilkan prestasi belajar matematika yang lebih baik daripada model pembelajaran konvensional. konvensional.Sedangkan model pembelajaran Card Sort juga berpengaruh secara signifikan dengan pembelajaran model lain, dibuktikan dengan penelitian yang telah dilakukanoleh Anis Mufidah Ulfa, Hadi Mulyono, Sularmi, Theresia Sri Suryani, Nanang Heryana, Ahmad Yani Rena Renteta, Rapani, Asmaul Khair, Melina Budiawati, Nelly Astuti, Muncarno, Etik Desti Haryati, Mugiadi, Suwarjo, Muncarno

Pemaparan hasil analisis data dapat disimpulkan bahwa terdapat perbedaan nilai awal dan nilai akhir dalam penggunaan model pembelajaran Make a Match dan Card Sort dalam pencapaian hasil belajar siswa kelas 4 SD Gugus Diponegoro Kecamatan Sidorejo. Namun hasil dalam penelitian menunjukkan bahwa dalam penerapan model pembelajaran kooperatif tipe Make a Match lebih tinggi secara signifikan daripada model pembelajaran Make a Match dengan dibandingkan hasil belajar Matematika siswa kelas 4 SD di Gugus Diponegoro Kecamatan Sidomukti Salatiga.

\section{SIMPULAN DAN SARAN \\ 1. Simpulan}

Berdasarkan analisi yang telah dilakukan dan dibahas pada bab IV dapat ditarik simpulan bahwa dalam penerapan model pembelajaran Make a Match lebih unggul daripada model pembelajaran Card Sort. Simpulan tersebut berdasarkan uji $\mathrm{T}$ yang telah dilakukan terhadap nilai pretest dan posttest kelompok eksperimen 1 dan kelompok eksperimen 2 dimana thitung > daripada ttabel.

\section{Saran}

Berdasarkan hasil penelitian yang telah dilakukan, maka terdapat beberapa saran yang ditujukan kepada :

a. Guru

Hasil penelitian menunjukkan bahwa, guru dapat menerapkan model pembelajaran kooperatif tipe Make a Match dan dapat digunakan dalam materi Tema 8 Sub Tema 2 Pembelajaran 3 yang disesuaikan dengan pemahaman guru mengenai model, karakteristik materi, dan kebutuhan siswa.

b. Siswa

Model Pembelajaran Kooperatif tipe Make a Match dan Card Sort dalam materi Tema 8 Sub Tema 3 Pembelajaran 3 diharapkan dapat diterapkan kepada siswa supaya siswa lebih antusias dalam mengikuti pembelajaran tersebut.

c. Kepala Sekolah

Kepala Sekolah dapat memperkenalkan model pembelajaran tipe Kooperatif Make a Match berbantuan puzzle dan Card sort berbantuan puzzle pada guru - guru, supaya guru dapat menciptakan suasana pembelajaran yang menyenangkan.

d. Peneliti Selanjutnya

Hasil penelitian ini dapat digunakan sebagai referensi untuk mengembangkan penelitian selanjutnya, dengan memperhatikan kekurangan yang ada dalam penelitian ini agar menjadi perbaikan bagi penelitian berikutnya.

\section{UCAPAN TERIMA KASIH}

Penulis mengucapkan terima kasih kepada Dr Mawardi, M.Pd selaku Pembimbing 1 dan Ibu Suhandi Asturi S.Pd,M.Pd selaku Pembimbing 2 yang senantiasa memberikan bimbingan, nasehat, dan motivasi kepada penulis sehingga penelitian ini dapat terselesaikan dengan baik. 


\section{DAFTAR PUSTAKA}

[1] Assa, E. R. (2015). Strategi of Learning. Yogyakarta: Araska.

[2] Astuti, S. (2016). Penerapan supervisi akademik untuk meningkatkan kompetensi guru dalam menyusun administrasi penilaian di sd laboratorium uksw. Scholaria: Jurnal Pendidikan dan Kebudayaan, 6(1), 117-126.

[3] Darmadi, H. (2011). Metode Penelitian Pendidikan. Bandung: Alfabeta.

[4] Huda, M. (2013). Model - Model Pengajaran dan Pembelajaran. Yogyakarta: Pustaka Pelajar.

[5] Isjoni. (2007). Pembelajaran Visioner . Yogyakarta: Pustaka Pelajar.

[6] Kurniasih, \& Sani. (2016). Ragam Pengembangan Model Pembelajaran Untuk Peningkatan Profesionalitas Guru. Jakarta: Kata Pena.

[7] Kusumawati, H., \& Mawardi, M. (2016). Perbedaan Penerapan Model Pembelajaran Kooperatif Tipe NHT dan STAD Ditinjau dari Hasil Belajar Siswa. Scholaria: Jurnal Pendidikan dan Kebudayaan, 6(3), 251-263.

[8] Mawardi, M., \& Mariati, M. (2016). Komparasi Model Pembelajaran Discovery Learning Dan Problem Solving Ditinjau Dari Hasil Belajar Ipa Pada Siswa Kelas 3 Sd Di Gugus DiponegoroTengaran. Scholaria: Jurnal Pendidikan dan Kebudayaan, 6(1), 127-142.

[9] Mawardi.(2017).Merancang Model Pembelajaran. Scholaria: Jurnal Pendidikan dan Kebudayaan.

[10]Setianingrum, M., Hariyadi, S., \& Prihatin, J. (2015). Pengaruh Model Pembelajaran Kooperatif Make A Match Berbantuan Media Benda Asli Terhadap Hasil Belajar Matematika Siswa Kelas IV. e-Journal PGSD Universitas Pendidikan Ganesha, 8.

[11] Slameto. (2012). Penelitian dan Inovasi Pendidikan. Salatiga: Widya Sari Press Salatiga.

[12]Slameto. 2010. Belajar \& Faktor-Faktor yang Mempengaruhinya. Jakarta: Rineka Cipta

[13]Sudjiono, A. (2011). Evaluasi Pendidikan. Jakarta: PT Raja Grafindo.

[14]Sugiono. (2010). Penelitian Pendidikan. Bandung: Alfabeta.

\section{Biografi Penulis Utama}

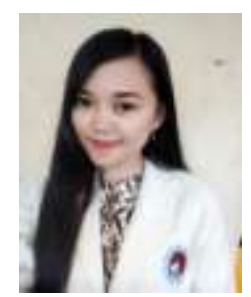

Penulis bernama lengkap "Tisia Selvy Fynata". Lahir di Desa Dukuh Krajan Salatiga Jawa Tengah pada tanggal 30 November 1994 dari pasangan Titis Guncoro dan Almarhum Titik Ngatminem. Penulis adalah anak pertama dari 2 bersaudara. Pendidikan sekolah dasar dimulai dari SDN Salatiga o6. Setelah itu melanjutkan pendidikan sekolah menengah ke SMPN 5 Salatigadan terakhir di SMA Kristen o1 Salatiga. Kemudian penulis melanjutkan studi ke perguruan tinggi di Program Studi Pendidikan PGSD FKIP Universitas Kristen Satya Wacana pada tahun 2014 Kritik, saran, maupun hal-hal yang berkaitan dengan kelanjutan atau pengembangan dari hasil penelitian ini bisa dikirim ke email penulis di selvyfynata@gmail.com 